\title{
Mitigation of Wastewater-Borne Chlorpyrifos in Constructed Wetlands: the Role of Vegetation on Partitioning
}

\author{
Chuan Wang ${ }^{1,2}$, Biyun Liu ${ }^{1}$, Dong Xu' ${ }^{1}$, Dan Zhang ${ }^{1,2}$, \\ Feng He${ }^{1}$, Qiaohong Zhou ${ }^{1 *}$, Zhenbin Wu ${ }^{1}$ \\ ${ }^{1}$ State Key Laboratory of Freshwater Ecology and Biotechnology, Institute of Hydrobiology, \\ Chinese Academy of Sciences, Wuhan 430072, China \\ ${ }^{2}$ University of Chinese Academy of Sciences, Beijing 100049, China
}

Received: 20 April 2016

Accepted: 26 July 2016

\begin{abstract}
Constructed wetlands (CWs) are regarded as a risk mitigation strategy for alleviating the risks associated with agricultural runoff that contains pesticides. We investigated the partitioning pattern of wastewater-borne chlorpyrifos, a widely used organophosphorus pesticide, in non-vegetated and vegetated CWs. Removal rates of chlorpyrifos calculated from inflow and outflow concentrations ranged from $87.65 \%$ to $96.57 \%$. The average removal rate was significantly higher and more stable in vegetated CWs than in non-vegetated CWs. As determined using a mass-balance method, outflows, macrophytes, substrate micro-degradation, and "other" accounted for $5.23 \%, 22.7 \%, 15.96 \%$, and $56.11 \%$, respectively, of the chlorpyrifos in the vegetated system. Of all Iris pseudoacorus organs examined, the rhizome was dominant in biomass and gathered the largest amount of chlorpyrifos. Except for the uptake of chlorpyrifos by plants, the primary difference between vegetated and non-vegetated CWs was that there was a relatively low potential for chlorpyrifos micro-degradation and volatilization and photolysis in vegetated CWs than in non-vegetated CWs. Identification of this partitioning pattern elucidates the mechanisms underlying chlorpyrifos removal from wastewater in CWs.
\end{abstract}

Keywords: constructed wetlands (CWs), chlorpyrifos, macrophyte, partitioning pattern, microbial degradation

\section{Introduction}

Chlorpyrifos [O,O-diethyl O-(3,5,6-trichloro2-pyridinyl) phosphorothioate] is a broad-spectrum organophosphorus pesticide that has been applied

*e-mail: qhzhou@ihb.ac.cn worldwide in agricultural production for almost 50 years [1]. Approximately $140,000 \mathrm{t}$ of chlorpyrifos is applied annually on a global scale, accounting for $1 / 3$ of total organophosphorus pesticide use. Annually, 5,000 t of the active ingredient is used in the United States and 18,000 $t$ is used in China [2-3]. The compound was banned from household use by the U.S. Environmental Protection Agency [4] and is also subject to special regulations by the European Union Water Framework Directive [5]. 
Management practices have been explored to alleviate the increasing risks due to runoff containing chlorpyrifos, and constructed wetlands (CWs) are perceived as a risk mitigation strategy or best management practice [6-7]. CWs retain pesticides and herbicides. Under optimal conditions, the chlorpyrifos removal efficiency from subsurface flow CWs is $97.9 \%$ [8]. The mean peak pesticide concentrations can be reduced by approximately $91 \%$ in a vegetated cell that receives a mixture of five pesticides [9].

CWs remove pollutants through the combined effects of physical, chemical, and biological processes. Preliminary studies on the removal mechanisms and fate of pesticides have been conducted in terms of sedimentation of pesticide-laden particles, which is influenced by hydraulic retention time (HRT) and vegetation density [10]. Researchers have also explored the percentage of total retained pesticides in sediment and plants [7, 9]. Chlorpyrifos is reportedly more readily adsorbed by plants than by soils, and partitioning coefficients are at least an order of magnitude greater for plants than for soils [11]. Macrophytes growing in CWs have at least 16 properties that affect their environments, such as filtering out large debris, taking up nutrients, providing surfaces for bacterial growth, and releasing oxygen, antibiotics, and other chemicals [12]. Microorganisms are likely to have greater potential for contaminant degradation than plants because of their large surface area and high metabolic rate. Plants are reported to remove chlorpyrifos from wastewater at a rate of up to $0.2 \mathrm{mg} \mathrm{L}^{-1} \mathrm{~d}^{-1}$ [13], whereas bacteria and fungi remove chlorpyrifos at a rate ranging between 7.4 and $12.1 \mathrm{mg} \mathrm{L}^{-1} \mathrm{~d}^{-1}$ [14]. Plant-microbe association is a common strategy in pollution remediation; however, the ways in which vegetation influences the roles of microbes in CWs is not well known.

The aim of the present study was to elucidate the percentage contribution of pathways to the removal of chlorpyrifos from CWs, especially the role of vegetation and its impact on microbial degradation. The results of this study provide insight into the chlorpyrifos partitioning patterns and removal mechanisms in CWs.

\section{Materials and Methods}

\section{Reagents}

Chlorpyrifos (purity 99.9\%) and Supelclea ENVI18 cartridges were purchased from the Sigma-Aldrich Co. Acetone, ethyl acetate, and methyl alcohol were of chromatographic grade.

\section{Pilot-scale CWs}

Experimental systems were placed in the open air in Wuhan, China (30.55 E and 114.36 N). Six pilot-scale vertical flow CWs, made from polyethylene (PE) columns with a height of $600 \mathrm{~mm}$ and a diameter of $500 \mathrm{~mm}$, were filled to a depth of $300 \mathrm{~mm}$ with washed river sand (mainly $\mathrm{Si}_{2} \mathrm{O}_{3}, \mathrm{Al}_{2} \mathrm{O}_{3}$, and $\mathrm{Fe}_{2} \mathrm{O}_{3}, 1-5 \mathrm{~mm}$ in diameter) as substrate. Three of the columns were then planted with three uniform Iris pseudoacorus (I. pseudoacorus) plants (vegetated CWs) and three columns were left unplanted (non-vegetated CWs).

\section{Experimental Design and Sampling}

During a 15-day acclimatization stage, each column received synthetic wastewater containing 7-8 $\mathrm{mg} \mathrm{L}^{-1}$ of total nitrogen (TN), $0.2-0.4 \mathrm{mg} \mathrm{L}^{-1}$ of total phosphorus (TP), and 60-70 $\mathrm{mg} \mathrm{L}^{-1}$ of chemical oxygen demand (COD) as inflow water. A 30-day experimental stage followed immediately after acclimation. In the experimental stage, chlorpyrifos was added to the inflow water at a final concentration of $1 \mathrm{mg} \mathrm{L}^{-1}$. This concentration is between the solubility $\left(1.39 \mathrm{mg} \mathrm{L}^{-1}\right.$ at $\left.25^{\circ} \mathrm{C}\right)$ of chlorpyrifos and the chlorpyrifos concentration of contaminated water found in the field [15-16]. Hydraulic load was $25.48 \mathrm{~mm} \mathrm{~d}^{-1}$ and hydraulic retention time (HRT) was two days.

Outflow water samples were collected on days 4, 7, 17, and 29. Samples of I. pseudoacorus were harvested after the experimental stage and leaves, stems, rhizomes, and roots were separated. Substrate samples were collected 48 $\mathrm{h}$ after the first and last chlorpyrifos application. Substrate samples were collected from five separate sites in each column. All substrate samples were approximately of the same size and were collected from the same height. After collection, substrate samples were homogenized, placed in sterilized centrifuge tubes, and transported to the laboratory, where they were stored at $-20^{\circ} \mathrm{C}$. Plant samples were ground in liquid nitrogen immediately after harvest and stored at $-80^{\circ} \mathrm{C}$.

\section{Extraction and Detection of Chlorpyrifos}

Chlorpyrifos in water samples was extracted by solid phase extraction (SPE) with a mean recovery of $91.03 \%$. ENVI-18 cartridges were conditioned with $5 \mathrm{~mL}$ methanol followed by $5 \mathrm{~mL}$ water samples. After adding the water samples, cartridges were dried by reduced pressure. Then the cartridges were eluted with $10 \mathrm{~mL}$ ethyl acetate. The extracts obtained were concentrated with $\mathrm{N}_{2}$ flow to a volume of $1 \mathrm{~mL}$.

Chlorpyrifos concentration in plant tissue was determined according to the method described by Xiao [17], with some modification. Mean recovery using the modified method was $95.00 \%$. Two grams of plant tissue were placed in a $50 \mathrm{~mL}$ capped centrifuge tube containing a mixture of $10 \mathrm{~g}$ anhydrous sodium sulfate and $30 \mathrm{~mL}$ acetone. Samples were homogenized by highspeed dispersator (4,000 rpm, $6 \mathrm{~min}$ ) and then centrifuged $(6,000 \mathrm{rpm}, 10 \mathrm{~min})$ at $4^{\circ} \mathrm{C}$. The supernatant was transferred to a fresh centrifuge tube and the extraction procedure was repeated using $20 \mathrm{~mL}$ acetone. The organic extracts were then passed through a column packed with (from top to bottom) $2 \mathrm{~g}$ anhydrous sodium sulfate, a mixture of $0.5 \mathrm{~g}$ activated carbon $(0.5 \mathrm{~g}$ celetom and $4 \mathrm{~g}$ neutral aluminum oxide), and $2 \mathrm{~g}$ anhydrous sodium sulfate. The column 
was eluted with $10 \mathrm{~mL} \times 5$ ethyl acetate, and after passing through the column the extracts were concentrated with $\mathrm{N}_{2}$ flow to a volume of $1 \mathrm{~mL}$.

Chlorpyrifos concentration in substrate was determined as follows with mean recovery of $90.90 \%$. Ten grams of substrate was placed in a $250 \mathrm{~mL}$ Erlenmeyer flask containing a mixture of $10 \mathrm{~g}$ anhydrous sodium sulfate and $30 \mathrm{~mL}$ acetone and shaken on a rotary shaker (at $200 \mathrm{rpm}$ ) for $1 \mathrm{~h}$. The liquid was transferred to a rotary evaporation flask and the extraction procedure was repeated using $20 \mathrm{~mL}$ acetone. The organic extracts were passed through a column packed with (from top to bottom) $2 \mathrm{~g}$ anhydrous sodium sulfate, $5 \mathrm{~g}$ silica gel powder, and $2 \mathrm{~g}$ anhydrous sodium sulfate. The column was eluted with $10 \mathrm{~mL} \times 5$ ethyl acetate and after passing through the column, extracts were concentrated with $\mathrm{N}_{2}$ flow to a volume of $1 \mathrm{~mL}$. The powder-like materials in the column were all burned using a muffle furnace before use.

Gas chromatograph (GC) analysis was performed using an Agilent 6890N gas chromatograph (Agilent Technologies, USA) equipped with an Agilent 5793 inert MSD. A fused silica capillary column (DB-5 ms, $0.25 \mathrm{~mm} \times 30 \mathrm{~mm} \times 0.1 \mu \mathrm{m})$ was employed. The GC oven temperature program consisted of an initial temperature of $50^{\circ} \mathrm{C}$ for $2 \mathrm{~min}$, followed by a ramp of $20^{\circ} \mathrm{C} \mathrm{min}^{-1}$ to $280^{\circ} \mathrm{C}$. The injector temperature was $250^{\circ} \mathrm{C}$ and the injected volume was $1 \mu \mathrm{L}$. Helium (purity $>99.999 \%$ ) was used as carrier gas at a constant flow rate of $1 \mathrm{~mL} \mathrm{~min} \mathrm{~m}^{-1}$.

\section{Degradation Potential of Chlorpyrifos by Microorganisms}

Freshly collected substrate $(10 \mathrm{~g})$ was added to 90 $\mathrm{mL}$ sterile water in a $100 \mathrm{~mL}$ centrifuge tube and then vortexed thoroughly. Sterilized substrate was taken with the same process as the control group. After vortexing, one $\mathrm{mL}$ suspension was added to $100 \mathrm{~mL}$ culture medium and incubated at $30^{\circ} \mathrm{C}$. After $48 \mathrm{~h}, 20 \mathrm{~mL}$ of the resultant culture was centrifuged $\left(5,000 \mathrm{rpm}, 4^{\circ} \mathrm{C}, 10 \mathrm{~min}\right)$. The supernatant was discarded and the pellet was washed by adding $20 \mathrm{~mL}$ normal saline to the centrifuge tube, mixed thoroughly by vortexing and centrifuging again. The washing step was repeated three times. Inoculum was prepared by adding sterile water to the washed solids until the $\mathrm{OD}_{400}$ was 2.0. Culture medium $(\mathrm{pH}$ 7.0) was prepared that consisted of $0.2 \mathrm{~g} \mathrm{~L}^{-1} \mathrm{MgSO}_{4} \cdot 7 \mathrm{H}_{2} \mathrm{O}, 0.1 \mathrm{~g} \mathrm{~L}^{-1} \mathrm{~K}_{2} \mathrm{HPO}_{4}, 0.1 \mathrm{~g} \mathrm{~L}^{-1}$ $\left(\mathrm{NH}_{4}\right)_{2} \mathrm{SO}_{4}, 0.4 \mathrm{~g} \mathrm{~L}^{-1} \mathrm{CaSO}_{4}, 0.001 \mathrm{~g} \mathrm{~L}^{-1} \mathrm{FeSO}_{4} \cdot 7 \mathrm{H}_{2} \mathrm{O}, 10 \mathrm{~g}$ $\mathrm{L}^{-1}$ glucose, and $5 \mathrm{~g} \mathrm{~L}^{-1}$ peptone in deionized water. Culture medium $(20 \mathrm{~mL})$ containing $100 \mathrm{mg} \mathrm{L}^{-1}$ chlorpyrifos and 1 $\mathrm{mL}$ inoculum were mixed in a $50 \mathrm{~mL}$ Erlenmeyer flask and incubated at $30^{\circ} \mathrm{C}$ (nine replicates for each sample). The chlorpyrifos concentrations in the flasks were determined 2,4 , and 8 days after the start of incubation.

\section{Data Analysis}

Differences among outflows, substrates, plant tissues, and microbial transformations were analyzed by one- way ANOVA with least significant difference (LSD) for multiple comparisons, and mean values differences were regarded as significant at the 0.05 level. Calculations were performed using the statistical program PAW version 20.0 [18]. Mass balance of chlorpyrifos portioning in CWs was calculated as follows:

- Substrates: chlorpyrifos remaining in substrates at the end of the experiment.

- Outflows: average chlorpyrifos concentration in effluent multiplied by total effluent volume from each CW.

- Macrophytes: sum of chlorpyrifos accumulation in all plant tissues.

- Micro-degradation, volatilization, and photolysis: the difference between total influent chlorpyrifos and the sum of the chlorpyrifos contained in substrates, outflows, and macrophytes.

\section{Results and Discussion}

\section{Removal Efficiency}

Removal rates of chlorpyrifos by vertical flow CWs ranged from $87.65 \%$ to $96.57 \%$ (Table 1 ). The average removal rate was significantly higher in the vegetated group $(95.63 \%)$ than in the non-vegetated group (92.64\%). The removal rate on day 4 was remarkably lower than on other sampling days. In the vegetated group, there were no other differences in removal rate between days. In the non-vegetated group, although there was no difference in removal rates on days 7 and 17, the removal rate was higher on day 7 than on days 4 and 29. Removal rates were significantly higher on days 4 and 29 in vegetated systems than in non-vegetated systems. Moreover, the removal rates fluctuated less in the vegetated group than in the non-vegetated group, as indicated by the standard deviations for the overall mean removal rates $(0.0162$ and 0.0413 , respectively).

CWs are effective for removing other organic environmental pollutants, such as monochlorobenzene (MCB) and perchloroethylene (PCE). Chen et al. found that removal rates of $\mathrm{MCB}$ and $\mathrm{PCE}$ along the flow path was faster in planted CWs than in unplanted CWs [19]. Peak concentrations of mixed pesticides are reportedly reduced by $72 \%$ in non-vegetated CWs and $91 \%$ in vegetated $\mathrm{CWs}$, representing toxic unit (TU) reductions of $79 \%$ and $95 \%$, respectively [9]. Vegetation also plays an important role in resisting algal blooms in surface flow CWs installed to handle both nutrients and pesticides [20]. The presence of emergent vegetation is critical for managing large wetland treatment systems, especially those with low P loadings [21]. Therefore, vegetation is an indispensable part of CWs installed for pesticide or inorganic nutrient elimination. Although the removal efficiency in vegetated $(95.72 \%)$ and non-vegetated $(91.67 \%)$ CWs after $29 \mathrm{~d}$ were similar in the present study, the difference was statistically significant. In this study, vegetation did not have as great an influence as that 
Table 1. Removal efficiency of chlorpyrifos and $\mathrm{pH}$ values in the inflows and outflows of pilot-scale constructed wetlands. Letters a and $\mathrm{b}$ represent significant differences between vegetated and non-vegetated systems on the same sampling date.

\begin{tabular}{|c|c|c|c|c|c|}
\hline Sampling time (d) & & 4 & 7 & 17 & 29 \\
\hline \multirow{2}{*}{$\begin{array}{c}\text { Removal rates of } \\
\text { chlorpyrifos (\%) }\end{array}$} & Vegetated & $93.97 \pm 1.62^{\mathrm{a}}$ & $96.57 \pm 1.46^{\mathrm{a}}$ & $96.14 \pm 1.71^{\mathrm{a}}$ & $95.72 \pm 0.64^{\mathrm{a}}$ \\
\cline { 2 - 6 } & Non-vegetated & $87.65 \pm 3.77^{\mathrm{b}}$ & $96.12 \pm 1.28^{\mathrm{a}}$ & $94.33 \pm 1.03^{\mathrm{a}}$ & $91.67 \pm 2.32^{\mathrm{b}}$ \\
\hline \multirow{2}{*}{$\mathrm{pH}$ value } & inflow & 7.67 & 7.41 & 7.48 & 7.56 \\
\cline { 2 - 6 } & Vegetated outflow & $7.23-7.41$ & $7.21-7.34$ & $7.27-7.30$ & $7.25-7.29$ \\
\cline { 2 - 6 } & $\begin{array}{c}\text { Non-vegetated } \\
\text { outflow }\end{array}$ & $7.05-7.20$ & $6.92-7.18$ & $7.01-7.14$ & $6.98-7.13$ \\
\hline
\end{tabular}

described in previous studies, but it did contribute to the stability of the purification effect.

In addition to the direct association between chlorpyrifos degradation and vegetation, chlorpyrifos degradation was related to $\mathrm{pH}$, which was lower in nonvegetated $\mathrm{CWs}$ than in vegetated $\mathrm{CWs}$ (Table 1 ). The rate of chlorpyrifos degradation was low in acidic soils, but increased considerably with increasing soil $\mathrm{pH}$ (4.7-8.4). High $\mathrm{pH}$ not only helps to develop enhanced chlorpyrifos degradation, but is also required to maintain it over long periods [22]. In groundwater, the half-life of chlorpyrifos decreases from $49.9 \mathrm{~d}$ to $44.4 \mathrm{~d}$ when $\mathrm{pH}$ increased from 7 to 8.5 [23]. In the present study, the $\mathrm{pH}$ of inflow and outflow water decreased from 7.53 to 7.05 after CW treatment, as has been previously reported for horizontal sub-surface flow CWs treated with chlorpyrifos $(\mathrm{pH} 6.9$ to 5.0) [24]. Therefore, the elimination of chlorpyrifos by CWs may involve consumption of alkali materials, and more of these materials may be used in the absence of vegetation than when vegetation is present.

\section{Residues in the Substrate}

There were no differences in chlorpyrifos concentration of substrate samples between vegetated and non-vegetated CWs at either the start or end of the experimental stage. In

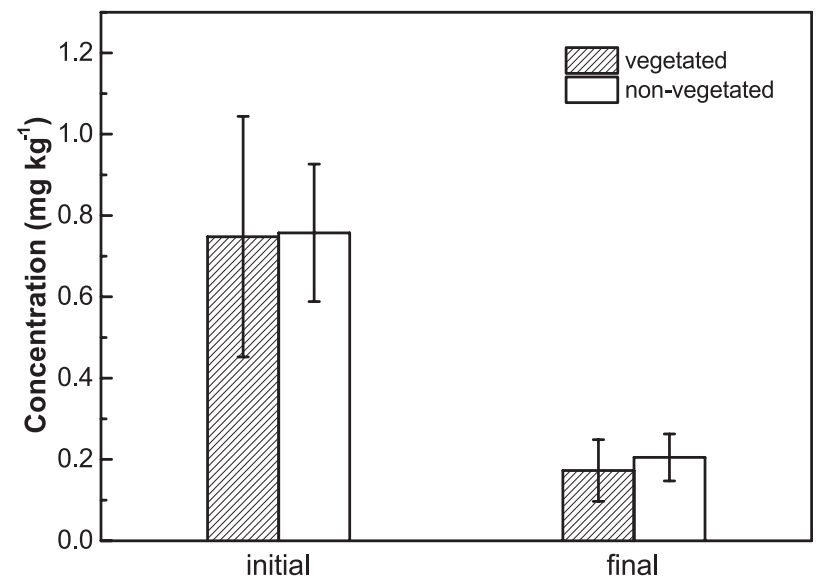

Fig. 1. Chlorpyrifos residues in substrates at the start and end of a 30-d experimental stage. Initial time is $48 \mathrm{~h}$ after the first inflow of wastewater-borne chlorpyrifos in experimental CWs, and terminative time is $48 \mathrm{~h}$ after the last inflow. spite of repeated inflow, chlorpyrifos remaining in substrate decreased drastically from $0.76 \mathrm{mg} \mathrm{kg}^{-1}$ to $0.17 \mathrm{mg} \mathrm{kg}^{-1}$ between the initial and terminal phases of the experiment (Fig. 1). Pesticides in the passing flow can be retrained in CWs by sedimentation or adsorption and retained pesticides may undergo biotic and abiotic transformations [25]. Transformations in the present study included microorganism degradation, plant uptake, volatilization into the air, and natural photolysis. These transformations were similar to those previously described [26-28]. The significant decrease in substrate chlorpyrifos between the initial and terminal stages of the experiment suggest that the potential of chlorpyrifos transformation increased over the course of the experiment. However, less than $2.5 \%$ of added chlorpyrifos is reported to mineralize in wetland microcosms [29]. The mineralization that occurs is mostly due to microbial metabolism, as chlorpyrifos is rapidly degraded and mineralized to $\mathrm{CO}_{2}$ when the test soils are amended with enhanced microorganisms [22]. Further toxic assessments are needed to accurately determine the rate of ultimate chlorpyrifos mineralization in CWs.

\section{Uptake by Plant Tissues}

As shown in Fig. 2, the chlorpyrifos concentration in the rhizomes and roots of I. pseudoacorus was significantly higher than in leaves and stems; the rhizome and root

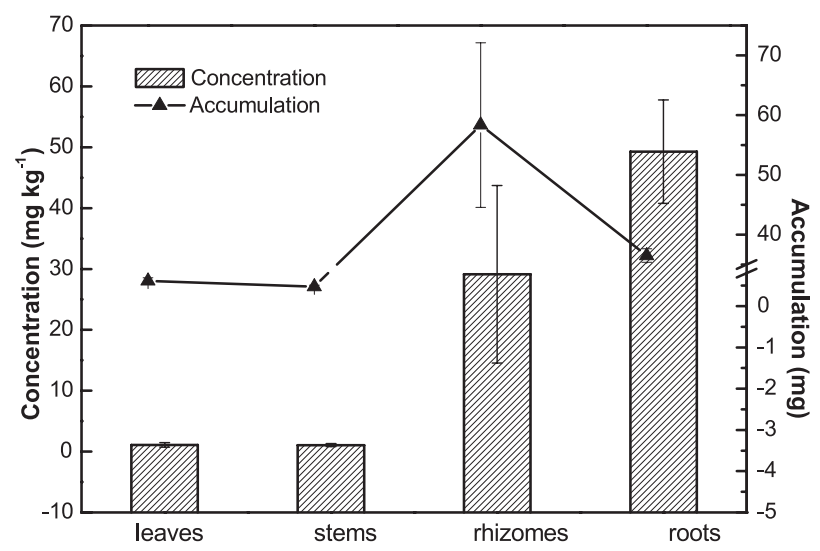

Fig. 2. Chlorpyrifos concentrations and total quantities in different tissues of I. pseudoacorus harvested from pilot-scale constructed wetlands. 
concentration was approximately 30 - to 50 -fold that of the leaf and stem concentration. There were no differences in chlorpyrifos concentration between rhizomes and roots or between plants and stems. Rhizomes accumulated the largest total amount of chlorpyrifos $(60.83 \%)$ absorbed by plants, followed by roots $(38.05 \%)$, leaves $(0.64 \%)$, and stems $(0.49 \%)$. The mass percentages of the four tissues were $37.79 \%, 27.19 \%, 19.66 \%$, and $15.35 \%$ for rhizomes, roots, leaves, and stems, respectively. Although rhizomes had the second-highest chlorpyrifos concentration, they had the greatest biomass, resulting in greater total accumulation in the rhizomes than in the roots. Therefore, plants with large rhizomes might be better for removing chlorpyrifos or other organophosphate pesticides than those with small rhizomes.

The octanol-water partition coefficient (Kow) has been used as an indicator of pesticide bioavailability and translocation from plant roots to the transpiration stream [30-31]. Chlorpyrifos is a lipophilic compound with a $\log$ Kow of 4.7 5.3 that can be quickly adsorbed on root surfaces and can cross the biomembrane, but is not readily transported from roots to aboveground tissues [32-34]. This explains why chlorpyrifos accumulation in I. pseudoacorus occurred primarily in underground parts. Plant harvest is one of the most important management practices for removing compounds that macrophytes have taken up from CWs [35]. However, increased methane emissions can occur after such harvests [36]. This may be more effective for focusing on transformation and utilization of chlorpyrifos in plant tissues rather than harvesting the aboveground biomass, as chlorpyrifos primarily accumulated in underground tissues. Plants possess a broad spectrum of enzymes that can metabolize or stabilize chemicals, and thus may prevent the dispersion of pesticide residues after plant death or shoot harvest [37]. Chlorpyrifos can be completely mineralized through a combination of plant metabolism and rhizosphere microbial breakdown $[32,37,38]$. Further research into the relationships between plants and microorganisms is needed in order to improve the efficiency of phytoremediation.

\section{Degradation Potential of Microorganisms}

As shown in Fig. 3, degradation rates of the two sterilized groups were nearly the same. Less than $30 \%$ of the total chlorpyrifos was degraded by abiotic factors after eight days of incubation. Compared with substrate collected at the initial time of the experiment, the average degradation rates increased by 23.23 and $44.23 \%$ for substrate collected from vegetated and non-vegetated CWs, respectively, at the end of the experiment. No differences were detected in chlorpyrifos degradation rate between samples collected from vegetated and nonvegetated CWs at the initial time. However, at the end of the experiment the degradation rate in samples from nonvegetated CWs was $12.56 \%$ higher than that in samples from vegetated CWs.

Competition for chlorpyrifos may have existed between microorganisms and plants. As discussed in 3.3,

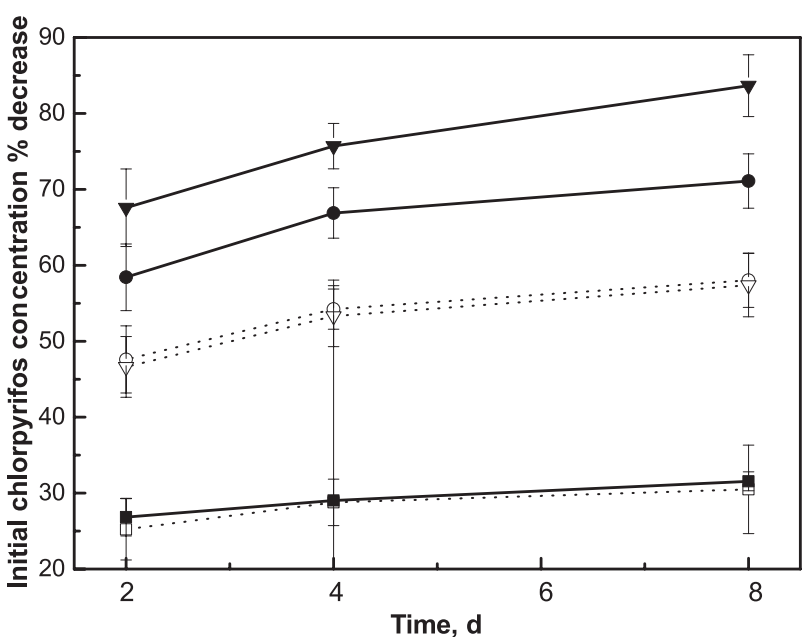

Fig. 3. Microbial transformation efficiency of chlorpyrifos in substrate samples from vegetated and non-vegetated CWs. Closed squares represent sterilized controls, closed circles represent vegetated CWs, and closed triangles represent nonvegetated CWs at the end of a 30-day experimental period. Open shapes represent the corresponding substrates at the start of the experimental period.

chlorpyrifos can be easily adsorbed onto the lipophilic structures of the root system and quickly cross the biomembrane. This decreases the chlorpyrifos available to microorganisms, thereby reducing the potential for microbial degradation. However, root systems can also act as a support for soil microflora. The exudates from roots, consisting of sugars, amino acids, and organic acids, enhance the development of bacteria and fungi biomass [39]. There is a positive correlation between chlorpyrifos loss and root biomass [40], which suggests that root biomass or planting density are important determinants of pesticide elimination. There may be some optimal ratio of pollution load to root biomass, at which point the balance between root exudates and chlorpyrifos availability maximizes chlorpyrifos degradation by microbes.

\section{Percentages of Chlorpyrifos Removal by Different Pathways}

An overall view of chlorpyrifos mitigation in vertical flow CWs is presented in Fig. 4. Residues in effluent water and substrate were less than $10 \%$ and $20 \%$ of input, respectively. The sum percentage of effluent water and substrate were slightly higher in non-vegetated systems $(28.11 \%)$ than in vegetated systems $(21.19 \%)$. Plant absorption accounted for $22.7 \%$ of the chlorpyrifos added to the system. The remainder is attributed to degradation by microorganisms, volatilization into the air, and natural light degradation. These processes were responsible for $56.11 \%$ and $71.89 \%$ of the chlorpyrifos added to the vegetated and non-vegetated systems, respectively.

Except for residues in outflows, substrates, and plant tissues, there was a $15.78 \%$ difference between vegetated and non-vegetated CWs in the chlorpyrifos mass. This could be attributed to the by-effects that vegetation brought 


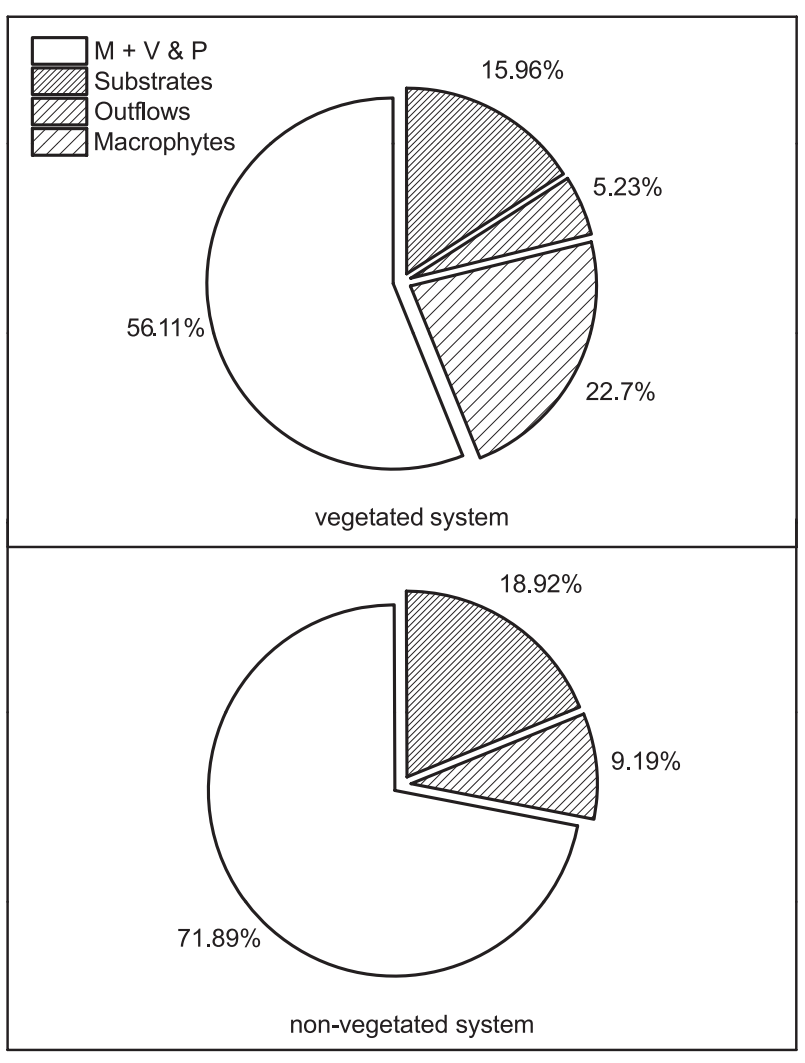

Fig. 4. Partitioning pattern of wastewater-borne chlorpyrifos in vegetated and non-vegetated constructed wetlands. Abbreviations: M, micro-degradation; V, volatilization; $\mathrm{P}$, photolysis.

about, including changes in microbial degradation, volatilization, and natural photolysis. Volatilization and photolysis might be inhibited by plant shading. The results reported in section 3.4 showed that the chlorpyrifos degradation potential by microorganisms was $12.56 \%$ higher in non-vegetated CWs than in vegetated CWs. If this proportion was subtracted from the sum discrepancy of $15.78 \%$, it could be extrapolated that $3.22 \%$ less chlorpyrifos was removed from vegetated CWs than from non-vegetated CWs by volatilization and natural light degradation (Fig. 5).

Racke reported that volatilization accounted for $2.6 \%$ of added chlorpyrifos from sand soil within 30 days [41]. In addition, when soils were sterile, complete

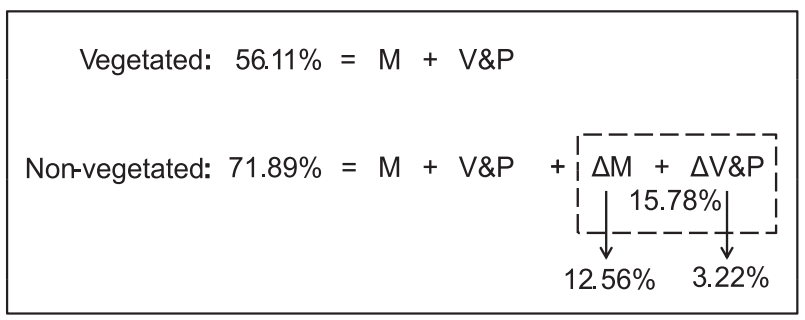

Fig. 5. Component analysis of the proportion of chlorpyrifos removed from constructed wetlands by a combination of microbes $(\mathrm{M})$, volatilization $(\mathrm{V})$, and photolysis $(\mathrm{P})$. inhibition of chlorpyrifos hydrolysis was observed, indicating the involvement of soil microorganisms in this process. Photolysis occurs only at moderate rates under neutral $\mathrm{pH}$ conditions [42]. Consequently, it was likely that volatilization and photolysis accounted for only a minuscule portion of the chlorpyrifos removed from the water in the present study.

\section{Conclusions}

This investigation was conducted to determine the contribution percentage of different pathways to chlorpyrifos removal in CWs, especially the role of vegetation and its impact on microbial degradation. Vegetation was a factor in maintaining the stability of chlorpyrifos removal in vertical flow CWs. Compared with other organs, the rhizomes of I. pseudoacorus accumulated the largest amount of chlorpyrifos. The micro-degradation potential of vegetated $\mathrm{CWs}$ was $12.56 \%$ lower than that of non-vegetated CWs, indicating competition between chlorpyrifos absorption by roots and availability for microorganisms. The distribution of chlorpyrifos in CWs was as follows: $15.96 \%$ remnant in substrate, $5.23 \%$ remnant in outflow, $22.7 \%$ taken up by macrophytes, and $56.11 \%$ combined removal by microbes, volatilization, and photolysis. The primary differences between chlorpyrifos distributions in vegetated and nonvegetated $\mathrm{CWs}$ were in the percentages associated with macrophytes and combined microbes, volatilization, and photolysis.

\section{Acknowledgements}

This study was supported by the Major Science and Technology Program for Water Pollution Control and Treatment of China's 12th Five-Year Plan (No. 2012ZX07101007-005) and the National Natural Science Foundation of China (Nos. 30870221, 51178452, and 50909091). We would like to thank R. Wang, K. Y. Kong, and D. J. Chen for their assistance in preparing and running the wetland and micro-degradation analysis for this project.

\section{References}

1. DOW AGROSCIENCES. Chlorpyrifos Protects. The Dow Chemical Company. http://www.chlorpyrifos.com/.

2. USEPA. Pesticide Industry Sales and Usage Report, Washington (DC): US Gov. Print. Office. 2011.

3. JIANG Z.H. Analysis of marketing and development trend of chlorpyrifos. The New Century Of Agrochem (China). 10, 45, 2010.

4. USEPA. Reregistration Eligibility Science Chapter for Chlorpyrifos Fate and Environmental Risk Assessment Chapter, Washington (DC): US Gov. Print. Office. 2000.

5. EUROPEAN COMMISSION. A Decision of the European Parliament and of the Council establishing the list of priority 
substances in the field of water policy Brussels, Belgium: European Commission Decision. 2000.

6. SCHULZ R. Field studies on exposure, effects, and risk mitigation of aquatic nonpoint-source insecticide pollution: A review. J. Environ. Qual. 33 (2), 419, 2004.

7. MOORE M.T., SCHULZ R., COOPER C.M., SMITH S., RODGERS J.H. Mitigation of chlorpyrifos runoff using constructed wetlands. Chemosphere. 46 (6), 827, 2002.

8. AGUDELO R.M., MACHADO C., AGUIRRE N.J., MORATO J., PEÑUELA G. Optimal conditions for chlorpyrifos and dissolved organic carbon removal in subsurface flow constructed wetlands. Int. J. Environ. Anal. Chem. 91 (7-8), 668, 2011.

9. ELSAESSER D., BLANKENBERG A.-G.B., GEIST A., MæHLUM T., SCHULZ R. Assessing the influence of vegetation on reduction of pesticide concentration in experimental surface flow constructed wetlands: Application of the toxic units approach. Ecol. Eng. 37 (6), 955, 2011

10. BUDD R., O'GEEN A., GOH K.S., BONDARENKO S., GAN J. Efficacy of Constructed Wetlands in Pesticide Removal from Tailwaters in the Central Valley, California. Environ. Sci. Technol. 43 (8), 2925, 2009.

11. ROGERS M.R., STRINGFELLOW W.T. Partitioning of chlorpyrifos to soil and plants in vegetated agricultural drainage ditches. Chemosphere. 75 (1), 109, 2009.

12. VYMAZAL J. Plants in constructed, restored and created wetlands. Ecol. Eng. 61, 501, 2013.

13. PRASERTSUP P., ARIYAKANON N. Removal of Chlorpyrifos by Water Lettuce (Pistia stratiotes L.) and Duckweed (Lemna minor L.). Int. J. Phytoremediat. 13 (4), 383, 2011.

14. MAYA K., SINGH R.S., UPADHYAY S.N., DUBEY S.K. Kinetic analysis reveals bacterial efficacy for biodegradation of chlorpyrifos and its hydrolyzing metabolite TCP. Process Biochem. 46 (11), 2130, 2011.

15. ANDERSON B.S., PHILLIPS B.A., HUNT J.W., WORCESTER K., ADAMS M., KAPELLAS N., TJEERDEMA R. S. Evidence of pesticide impacts in the Santa Maria River watershed, California, USA. Environ. Toxicol. Chem. 25 (4), 1160, 2006.

16. THOMATOU A.-A., ZACHARIAS I., HELA D., KONSTANTINOU I. Determination and risk assessment of pesticide residues in lake Amvrakia (W. Greece) after agricultural land use changes in the lake's drainage basin. Int. J. Environ. Anal. Chem. 93 (7), 780, 2013.

17. XIAOH.P. Studies on phytoremediation of organophosphorus pesticide triazophos polluted water by wetland plants, Wuhan, China: University of Chinese Academy of Sciences. 2009.

18. PAW. IBM SPSS Statistics for Windows, Version 20.0. IBM Corporation. 2009.

19. CHEN Z.B., WU S.B., BRAECKEVELT M., PASCHKE H., KASTNER M., MOSER H., KUSCHK P. Effect of vegetation in pilot-scale horizontal subsurface flow constructed wetlands treating sulphate rich groundwater contaminated with a low and high chlorinated hydrocarbon. Chemosphere. 89 (6), 724, 2012.

20. LIZOTTE R.E., MOORE M.T., LOCKE M.A., KROGER R. Effects of Vegetation in Mitigating the Toxicity of Pesticide Mixtures in Sediments of a Wetland Mesocosm. Water Air. Soil Poll. 220 (1-4), 69, 2011.

21. MOUSTAFA M.Z., WHITE J.R., COGHLAN C.C., REDDY K.R. Influence of hydropattern and vegetation on phosphorus reduction in a constructed wetland under high and low mass loading rates. Ecol. Eng. 42, 134, 2012.
22. SINGH B.K., WALKER A., MORGAN J.A.W., WRIGHT D.J. Effects of soil $\mathrm{pH}$ on the biodegradation of chlorpyrifos and isolation of a chlorpyrifos-degrading bacterium. Appl. Environ. Microb. 69 (9), 5198, 2003.

23. DRUZINA B., STEGU M. Degradation study of selected organophosphorus insecticides in natural waters. Int. J. Environ. Anal. Chem. 87 (15), 1079, 2007.

24. AGUDELO R.M., PENUELA G., AGUIRRE N.J., MORATO J., JARAMILLO M.L. Simultaneous removal of chlorpyrifos and dissolved organic carbon using horizontal sub-surface flow pilot wetlands. Ecol. Eng. 36 (10), 1401, 2010.

25. BUDD R., O'GEEN A., GOH K.S., BONDARENKO S., GAN J. Removal mechanisms and fate of insecticides in constructed wetlands. Chemosphere. 83 (11), 1581, 2011.

26. MOORE M. T., COOPER C.M., SMITH S., JR., CULLUM R.F., KNIGHT S.S., LOCKE M.A., BENNETT E.R. Diazinon mitigation in constructed Wetlands: Influence of vegetation. Water Air. Soil Poll. 184 (1-4), 313, 2007.

27. MOORE M.T., COOPER C.M., SMITH S., J.R., CULLUM R.F., KNIGHT S.S., LOCKE M.A., BENNETT E.R. Mitigation of two pyrethroid insecticides in a Mississippi Delta constructed wetland. Environ. Pollut. 157 (1), 250, 2009.

28. LOCKE M.A., WEAVER M.A., ZABLOTOWICZ R.M., STEINRIEDE R.W., BRYSON C.T., CULLUM R.F. Constructed wetlands as a component of the agricultural landscape: Mitigation of herbicides in simulated runoff from upland drainage areas. Chemosphere. 83 (11), 1532, 2011.

29. GEBREMARIAM S.Y., BEUTEL M.W. Effects of drain-fill cycling on chlorpyrifos mineralization in wetland sedimentwater microcosms. Chemosphere. 78 (11), 1337, 2010.

30. RYAN J.A., BELL R.M., DAVIDSON J.M., OCONNOR G.A. Plant uptake of non-ionic organic-chemicals from soils. Chemosphere. 17 (12), 2299, 1988.

31. BROMILOW R.H., CHAMBERLAIN K. Principles governing uptake and transport of chemicals. Lewis Publishers: London. 38, 1995.

32. ROMEH A.A. Phytoremediation of Water and Soil Contaminated with Imidacloprid Pesticide by Plantago Major, L. Int. J. Phytoremediat. 12 (2), 188, 2010.

33. BRIGGS G.G., BROMILOW R.H., EVANS A.A. Relationships between lipophilicity and root uptake and translocation of non-ionized chemicals by barley. Pestic. Sci. 13 (5), 495, 1982.

34. LEE K.Y., STRAND S.E., DOTY S.L. Phytoremediation of Chlorpyrifos by Populus and Salix. Int. J. Phytoremediat. 14, 48, 2012

35. TANAKA T.S.T., IRBIS C., WANG P., INAMURA T. Impact of plant harvest management on function and community structure of nitrifiers and denitrifiers in a constructed wetland. Fems Microbiol. Ecol. 91 (2), 1, 2015.

36. ZHU N., AN P., KRISHNAKUMAR B., ZHAO L., SUN L., MIZUOCHI M., INAMORI Y. Effect of plant harvest on methane emission from two constructed wetlands designed for the treatment of wastewater. J. Environ. Manage. 85 (4), 936, 2007.

37. PASCAL-LORBER S., LAURENT F. Phytoremediation Techniques for Pesticide Contaminations. In: Lichtfouse E., editor. Alternative Faming Systems, Biotechnology, Drought Stress and Ecological Fertilisation, New York (NY): Springer. 6, 77. 2011.

38. ANWAR S., LIAQUAT F., KHAN Q.M., KHALID Z.M., IQBAL S. Biodegradation of chlorpyrifos and its hydrolysis product 3,5,6-trichloro-2-pyridinol by Bacillus pumilus strain C2A1. J. Hazard. Mater. 168 (1), 400, 2009. 
39. WEYENS N., VAN DER LELIE D., TAGHAVI S., NEWMAN L., VANGRONSVELD J. Exploiting plantmicrobe partnerships to improve biomass production and remediation. Trends Biotechnol. 27 (10), 591, 2009.

40. SMITH K.E., PUTNAM R.A., PHANEUF C., LANZA G.R., DHANKHER O.P., CLARK J.M. Selection of plants for optimization of vegetative filter strips treating runoff from turfgrass. J. Environ. Qual. 37 (5), 1855, 2008.
41. RACKE K.D. Environmental fate of chlorpyrifos. Rev. Environ. Contam. T. 131, 1, 1993.

42. CHISHTI Z., HUSSAIN S., ARSHAD K.R., KHALID A., ARSHAD M. Microbial degradation of chlorpyrifos in liquid media and soil. J. Environ. Manage. 114, 372, 2013. 